\title{
The Evaluation of Portfolio Performance with Jensen Index Method toward Samuel Securities in January-December 2020
}

C.H. Asta Nugraha*

Business and Economic Faculty UNTAG Semarang

DOI: $10.36348 /$ sjef.2021.v05i02.001 | Received: 21.01 .2021 | Accepted: 04.02.2021 | Published: 10.02 .2021

*Corresponding author: C.H. Asta Nugraha

\section{Abstract}

This research aims to evaluate the portfolio performance which recommended by PT. Samuel Sekuritas Indonesia in January-December 2020 with Jensen Index by testing whether alpha $(\alpha)$ gained from the result of regression on excess return portofolio Samuel toward excess return market does not equal zero significantly. The research result showed that alpha $(\alpha)$ significantly does not equal zero.

Keywords: Jense Index, Excess Return, Alpha $(\alpha)$.

Copyright () 2021 The Author(s): This is an open-access article distributed under the terms of the Creative Commons Attribution 4.0 International License (CC BY-NC 4.0) which permits unrestricted use, distribution, and reproduction in any medium for non-commercial use provided the original author and source are credited.

\section{INTRODUCTION}

Portfolio defined as the collection of investments opportunity. The main purpose of making portfolio is to minimize the unsystematic risk from each stock that formed portfolio. Basically, the unsystematic risk can be omitted by diversification. A company or individual can make portfolio to invest money or diversify the real asset. Because of the limited time, money and knowledge of investment, usulally the company or individual will form their investment portfolio through Investment Company.

The investment company provides service to manage the investors fund in the form of portfolio from securities which is prospective and the investment company gets the fee from the service they served [1]. The composition of the security chosen can be stock, bond, or mix between stock and bond.

In order to attract the investors to invest their fund in a portfolio, the investment company must offer the significant return with certain risk. Therfore, the investment company should have the ability to form a portfolio for the investors. Whether their service can really form a better portfolio than the portfolio at random, this is interesting to be researched.

The evaluation toward portfolio performance which is formed by the investment company should be done in order to know whether the choice of securities formed be a portfolio will give a better return (pay attention to the risk) or not. According to Bodie [2] the measurement of portfolio performance can be done by these three methods:
1. Sharpe Index
2. Treynor Index
3. Jensen Index

Based on that background above, the researcher is interested in doing a research toward the portfolio recommended by PT. Samuel Sekuritas Indonesia in January-December 2020. In this research, the researcher used Jensen Index evaluation method with the major consideration that this method easily proved statistically and use beta as the risk measurement which is suitable with the Capital Asset Pricing Model (CAPM) concept.

\section{LITERATURE REVIEW Investment}

Investment is the action of investing fund on one or more assets physically or financially which put in a certain period in the future in order to get return from the fund have been invested.

In the real life, almost all investment contain uncertain element. The investors do not know the result that they will get from the investment they did. In this kind of situation, the investors will face the risk in their investment. The return and risk analysis will be 
important for the investors so that they can measure an investment or a set of investment.

\section{Return}

Return is the percentage of the whole current accepted by the investor during a certain period of time toward the purchase of the assets [3].

Return $=\frac{\text { Cash Payment Received }}{\text { Purchase assets }}+\frac{\text { Assets Price Change in acertain period }}{\text { Purchase assets }}$

In this evaluation portfolio performance, the return part which is in the form of price change will be very important because it is related to the assets choice done by the investment company.

$$
\mathrm{R}_{\mathrm{i}}=\frac{\mathrm{P}_{\mathrm{it}-} \mathrm{P}_{\mathrm{it}-1}}{\mathrm{P}_{\mathrm{it}-1}}
$$

Where:

$$
\begin{array}{ll}
\mathrm{R}_{\mathrm{i}} & \text { : return securities (stock) } \mathrm{i} \\
\mathrm{P}_{\mathrm{it}-1} & : \text { stock price } \mathrm{i} \text { period } \mathrm{t}-1 \\
\mathrm{P}_{\mathrm{it}} & : \text { stock price i periode } \mathrm{t}
\end{array}
$$

\section{Risk}

Risk is the possible differences rate between actual return and expected return [3]. The risk from financial asset can be measured with measurement absolute from the return rate variability called variance [3]. The equvalent size from the risk is standard deviation which is the square root of the variance.

\section{Portfolio Theory}

In practice, the investors often do diversification by combining kinds of securities in their investment. In other word, they form a security portfolio. It means that the portfolio is a collection of investment opportunities [1]. The main reason of the investors do diversification is to minimize the risk, like the saying "Don't put all your eggs in one basket".

\section{The Return of Portfolio}

The return rate of portfolio is weighted average from the return rate of each stock which form the portfolio with proportion weighted factor in each fund formed the portfolio itself [1].

Where,

$$
\mathrm{R}_{\mathrm{p}}=\sum_{\mathrm{i}=1}^{\mathrm{n}} \mathrm{X}_{\mathrm{i}} \cdot \mathrm{R}_{\mathrm{i}}
$$

$$
\begin{aligned}
& \mathrm{R}_{\mathrm{p}} \text { : portfolio return rate } \\
& \mathrm{R}_{\mathrm{i}}: \text { stock return rate } \mathrm{i} \\
& \mathrm{X}_{\mathrm{i}}: \text { stock proportion } \mathrm{i}
\end{aligned}
$$

\section{Portfolio Risk}

The risk of a portfolio measured by variance of standard deviation is quite complicated to be calculated because there is a correlation of each stock's return rate which formed the portfolio. Generally, the portfolio risk measured by variance [1] as formulated below :

$$
\sigma_{R p}^{2}=\sum_{i=1}^{n} X_{i}^{2} \sigma_{i}^{2}+\sum_{i=1}^{n} \sum_{j=1}^{n} X_{i} X_{j} \sigma_{i j}
$$

Where:

$\sigma_{\mathrm{Rp}}$ : portfolio risk

$\sigma_{i}^{2}:$ stock variance $i$

$\sigma_{\mathrm{ij}}$ : covariance of stock i with $\mathrm{j}$ stock

The calculation Portfolio Risk is getting complex if the total stock in portfolio getting more. In order to make easier calculation, this research will use Single Index Model to calculate the portfolio risk.

\section{Systematic Risk and Unsystematic Risk}

Based on Single Index Model, the risk can be divided into two components, they are systematic risk and unsystematic risk [2] so that:

$$
\sigma_{\mathrm{Rp}}^{2}=\beta_{\mathrm{p}}^{2} \sigma_{\mathrm{RM}}^{2}+\sigma_{\mathrm{ep}}^{2}
$$

Total Variance $=$ Systematic Risk + Unsystematic Risk

The risk will be there and it cannot be omitted by diversification and it is called as systematic risk. While the risk that can be omitted by diversification called as unsystematic risk.

Because mostly the investors act risk averse so they will choose the diversification if they know that the diversification will minimize the risk. Therefore, the risk that has been omitted because of diversification will be not relevant in risk calculation. The systematic risk will be relevant in risk calculation.

The systematic risk measured with beta coefficient which can be searched with regression the history return rate of a stock or portfolio as dependent variable and the history return rate of market index (for example IHSG) as the independent variable. The regression coefficient of the result calculation is beta $(\beta)$. Because the amount of $\sigma_{R M}^{2}$ is always same for each stock or portfolio, so the size of systematic risk determined by only the size of beta coefficient $(\beta)$ whether for stock or portfolio.

\section{According to Gruber, et al. [4], Single Index Model} has these characteristics

1. Portfolio Alpha $\left(\alpha_{\mathrm{p}}\right)$ is the weighted average from each alpha of the stock which formed portfolio so that

$\alpha_{p}=\sum_{i=1}^{n} X_{i} \alpha_{i}$

2. Portfolio Beta $\left(\beta_{\mathrm{p}}\right)$ is the weighted average each beta of the stock which formed portfolio so that

$\beta_{\mathrm{p}}=\sum_{\mathrm{i}=1}^{\mathrm{n}} \mathrm{X}_{\mathrm{i}} \beta_{\mathrm{i}}$

3. Portfolio Variance $\sigma_{R p}^{2}$ is the total of systematic risk with the unsystmatic risk so that $\sigma_{\mathrm{Rp}}^{2}=\beta_{\mathrm{p}}^{2} \cdot \sigma_{\mathrm{RM}}^{2}+$ $\sigma_{p}^{2}$ wih the value $\sigma_{p}^{2}=\sum_{i=1}^{n} X^{2}{ }_{i} \sigma^{2}{ }_{\text {ei }}$

Alpha $\left(\alpha_{\mathrm{i}}\right)$, beta $\left(\beta_{\mathrm{i}}\right)$ and variance each stock $\left(\sigma_{\text {ei }}^{2}\right)$ will obtained if each stock regressed toward IHSG. It can be 
used to calculate the portfolio risk in the form of standard deviation or beta.

\section{The Relation between the Return and the Risk Based on Capital Asset Pricing Model (CAPM)}

Capital Asset Pricing Model formally connects to the expected rate of return from a stock or portfolio with the relevant risk. The relation between the rate of return and $\beta$ from CAPM is the most common form used [3]. $\beta$ is the measurement of risk which is the most relevant for the risk that cannot be diversified in a portfolio. That relation stated that the rate of return expected by an investor, who invested on asset, has the same risk with the return rate on free asset risk added with risk premium and can be formulated sistematically as follow:

$$
E\left(R_{i}\right)=R_{f}+\left[E\left(R_{M}\right)-R_{f}\right] \beta_{i}
$$

Where,

$\mathrm{E}\left(\mathrm{R}_{\mathrm{i}}\right) \quad$ : return rate expected on stock $\mathrm{i}$

$\mathrm{R}_{\mathrm{f}} \quad$ : risk free rate

$E\left(R_{M}\right)$ : return rate expected on a portfolio market

$\beta_{\mathrm{i}} \quad$ : the systematic risk on stock $\mathrm{i}$

That equation can be changed into risk premium or excess retun by moving $R_{f}$ to the left side and do substraction on $E\left(R_{i}\right)$ so it will be :

$\mathrm{E}\left(\mathrm{R}_{\mathrm{i}}\right)-\mathrm{R}_{\mathrm{f}}=\left[\mathrm{E}\left(\mathrm{R}_{\mathrm{M}}\right)-\mathrm{R}_{\mathrm{f}}\right] \beta_{\mathrm{i}}$

In order to make easier interpretation, that equation above can be described in a chart with the vertical axis $E\left(R_{i}\right)-R_{f}$ and the horizontal axis $E\left(R_{M}\right)-$ $R_{f}$. The result will show that $\beta$ is the slope of the line that shows the relation between $E\left(R_{i}\right)-R_{f}$ with $E\left(R_{M}\right.$ $-R_{f}$ ) and that line cut off or go through the point of origin (zero point).

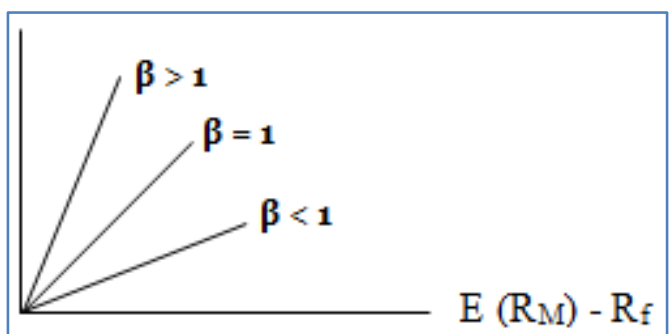

\section{Portfolio Performance Evaluation Method}

Based on the Capital Asset Pricing Model and the acknowledgment of the necessity inserting the return or risk William Sharpe, Jack Treynor and Michael Jensen developed the portfolio performance measurement around 1960s.

Those measurement often called as Composite (Risk Adjusted) Measure of Portfolio Performance which means that they insert return or risk in the portfolio performance evaluation[3]. Those measurements are Sharpe Index, Treynor Index, and Jensen Index which are often using until now.
As stated in the background of the research, this research will use Jensen Index evaluation method with major consideration that this will be easily proved statistically and use beta as the risk measurement which is suitable with the Capital Asset Pricing Model (CAPM) concept.

\section{Jensen Index}

Jensen performance measurement is like Treynor performance measurement which is based on Capital Asset Pricing Model (CAPM). The return rate expected on portfolio as stated as follow,

$$
\mathrm{E}\left(\mathrm{R}_{\mathrm{p}}\right)=\mathrm{R}_{\mathrm{ft}}+\beta_{\mathrm{p}}\left[\mathrm{E}\left(\mathrm{R}_{\mathrm{M}}\right)-\mathrm{R}_{\mathrm{ft}}\right]+\dot{\varepsilon}_{\mathrm{pt}}
$$

That equation used time period as based on ex ante. However, it can be applied at the same period as based on ex post if the investor's expectation mostly fulfilled. Empirically, that equation can be changed into [3].

$$
\mathrm{R}_{\mathrm{pt}}=\mathrm{R}_{\mathrm{ft}}+\beta_{\mathrm{p}}\left[\mathrm{R}_{\mathrm{Mt}}-\mathrm{R}_{\mathrm{ft}}\right]+\dot{\varepsilon}_{\mathrm{pt}}
$$

Where:

$\mathrm{R}_{\mathrm{pt}}$ : portfolio return during the certain period

$\mathrm{R}_{\mathrm{ft}}$ : risk free rate during the certain period

$\mathrm{R}_{\mathrm{Mt}}$ : market portfolio return (IHSG) during the certain period

$\dot{\varepsilon}_{\mathrm{pt}} \quad$ : portfolio random error during the certain period

That equation above can be changed in the form of excess return by moving $\mathrm{R}_{\mathrm{f}}$ to the left side and do substraction on $\mathrm{R}_{\mathrm{pt}}$ then it will be:

Where,

$$
\mathrm{R}_{\mathrm{pt}}-\mathrm{R}_{\mathrm{f}}=\beta_{\mathrm{p}}\left[\mathrm{R}_{\mathrm{Mt}}-\mathrm{R}_{\mathrm{ft}}\right]+\dot{\varepsilon}_{\mathrm{pt}}
$$

$\mathrm{R}_{\mathrm{pt}}-\mathrm{R}_{\mathrm{f}}$ : portfolio excess return

$\mathrm{R}_{\mathrm{Mt}}-\mathrm{R}_{\mathrm{f}}$ : market excess return

That equation can be tested by regression the portfolio excess return with market excess return. If it gets proportional return with the risk assumed and relation fufilled then there is no intercept (alpha) on regression and regression line goes through the point of origin (zero).

When that condition are met, according to Jensen, intercept or alpha $(\boldsymbol{\alpha})$ can be added to the equation as a tool to determine whether the performance of a portfolio belongs to superior or inferior. Therefore, that equation can be changed into:

$$
\mathrm{R}_{\mathrm{pt}}-\mathrm{R}_{\mathrm{ft}}=\alpha_{\mathrm{p}}+\beta_{\mathrm{p}}\left[\mathrm{R}_{\mathrm{Mt}}-\mathrm{R}_{\mathrm{ft}}\right]+\dot{\varepsilon}_{\mathrm{pt}}
$$

The equation above can be interprated as follow

1. If alpha significantly positive, the portfolio performance is superior

2. If alpha significantly negative, the portfolio performance is inferior 
3. If alpha is not different from zero significantly, the portfolio performance is suitable with market based on the risk adjusted

\section{Reserch Hypothesis}

$\mathrm{H}_{\mathrm{o}}: \alpha_{\mathrm{p}}=0$ (portfolio performance equals to market)

$\mathrm{H}_{\mathrm{a}}: \alpha_{\mathrm{p}} \neq 0$ (superior portfolio

p erformance), $\alpha=5 \%$

\section{RESEARCH METHOD \\ Data Resources}

This research aims to evaluate the portfolio performance that recommended by PT. Samuel Sekuritas Indonesia. Therefore, it is needed relevant data with the aim of this research. The data used in this research was secondary data that gained from the website of PT. Samuel Sekuritas Indonesia (samuel.eo.id), www.idx.co.id, BNI and other resources.

\section{Data Collected Method}

The data collected method used in this research by doing the observation, identification data which is relevant with the aim of this research as follow:

1. The stock price recommended by PT. Samuel Sekuritas Indonesia formed as portfolio in JanuaryDecember 2020.

2. Monthly Composite Stock Price Index in (IHSG) from January-December 2020.

3. Monthly Risk Free Rate from January-December 2020.

\section{Data analysis method}

As stated above that the aim of this research is to evaluate the portfolio which is formed and recommended by PT. Samuel Sekuritas Indonesia, therefore the analysis data of this research arranged as follow:

\section{Stock Rate of Return Analysis}

This analysis aims to calculate the rate of return monthly for each stock which formed portfolio and the rate of return IHSG [5].

Where:

Formula: $\mathrm{R}_{\mathrm{i}}=\frac{\mathrm{P}_{\mathrm{it}-\mathrm{P}_{\mathrm{it}-1}}}{\mathrm{P}_{\mathrm{it}-1}}$

$\mathrm{R}_{\mathrm{i}} \quad$ : stock rate of return $\mathrm{i}$

$\mathrm{P}_{\mathrm{it}-1}$ : stock price $\mathrm{i}$ in month $\mathrm{t}-1$

$\mathrm{P}_{\mathrm{it}} \quad$ : stock price $\mathrm{i}$ in month $\mathrm{t}$

\section{Portfolio Rate of Return Analysis}

This analysis aims to calculate the Portfolio

Rate of Return monthly.

Formula: $\mathrm{R}_{\mathrm{p}}=\sum_{\mathrm{t}=1}^{\mathrm{n}} \mathrm{X}_{\mathrm{i}}\left(\mathrm{R}_{\mathrm{i}}\right)$

Where

$\mathrm{R}_{\mathrm{p}} \quad$ : portfolio rate of return in month $\mathrm{t}$

$R_{i} \quad$ : stock's rate of return in month $t$

$\mathrm{X}_{\mathrm{i}} \quad$ : fund Proportion put in stock I

\section{Portfolio Risk Analysis}

This analysis aims to calculate the portfolio risk which is measured by beta $(\beta)$. Therefore, this research used Single Index Model in order to calculate the risk in stock or portfolio by regression the stock rate of return toward the rate of return in IHSG so that it obtained the regression coefficient as beta $(\beta)$.

\section{According to [4] Single Index Model has these characteristics as follow \\ 1. $\alpha_{\mathrm{p}}=\sum \mathrm{X}_{\mathrm{i}} \alpha_{\mathrm{i}}$ \\ 2. $\beta_{\mathrm{p}}=\Sigma \mathrm{X}_{\mathrm{i}} \beta_{\mathrm{i}}$ \\ 3. $\sigma_{\mathrm{p}}^{2}=\beta_{\mathrm{p}}^{2} \cdot \sigma_{\mathrm{M}}^{2}+\sigma_{\mathrm{ep}}^{2}$}

\section{Portfolio Performance Evaluation}

This evaluation aims to measure the portfolio performance by using Jensen Index. Formula:

$$
\mathrm{R}_{\mathrm{pt}}-\mathrm{R}_{\mathrm{f}}=\alpha_{\mathrm{p}}+\beta_{\mathrm{p}}\left[\mathrm{R}_{\mathrm{Mt}}-\mathrm{R}_{\mathrm{ft}}\right]+\dot{\varepsilon}_{\mathrm{pt}}
$$

Where,

$$
\begin{array}{lc}
\mathrm{R}_{\mathrm{pt}}-\mathrm{R}_{\mathrm{f}} & \text { : portfolio excess return } \\
\mathrm{R}_{\mathrm{Mt}}-\mathrm{R}_{\mathrm{f}} & : \text { market excess return } \\
\varepsilon_{\mathrm{pt}} & : \text { portfolio error random }
\end{array}
$$

\section{RESULT AND DISCUSSION}

In this research, the researcher will evaluate the portfolio recommended by PT. Samuel Sekuritas Indonesia in January-December 2020 with the data gained until November, because this research started in the berginning of December which aims to know whether the portfolio recommended PT. Samuel Sekuritas Indonesia is superior before the holding period end in December 2020 so that the investors will see the performance before deciding to invest in the portfolio recommended by PT. Samuel Sekuritas Indonesia.

As it explained in chapter 2, the meaning of rate of return in this research is the capital gain namely the price gap in the closing stock every last month with the closing price stock in the last month before. The price stock, IHSG and risk free rate chosen the monthly basis adjusted with the need to calculate Jensen Index. For the risk measurement, it is used beta which is suitable with Jensen Index formula. The risk measurement used Single Index Model by regression the rate of return in each stock with the rate of return in IHSG.

\section{Stock Rate Return Analysis}

The rate of return in each stock that form portfolio must be calculated before calculation the portfolio rate of return. Capital gain chosen as the rate return in calculation the rate of return in each stock with the consideration that the capital gain can represent the ability of the investment manager chooses the stock which undervalued consistently affected the portfolio performance.

After getting the data in the form of stocks recommended by PT. Samuel Sekuritas Indonesia in 
January-December 2020 included the price, IHSG and Risk Free Rate then the next step was calculating the rate return in each stock, IHSG and Risk Free Rate with the complete result as follow:

Table-1: The stock recommended by PT. Samuel Sekuritas Indonesia in January-December 2020

\begin{tabular}{|r|r|r|r|}
\hline Stock & Last Price $\mathbf{( R p )}$ & Target Price (Rp) & Upside (\%) \\
\hline BMRI & 6,975 & 8,900 & 27.6 \\
BBNI & 7,500 & 10,600 & 42.3 \\
ICBP & 11,400 & 13,200 & 15.8 \\
INDF & 7,950 & 9,500 & 19.5 \\
TLKM & 3,950 & 4,700 & 19.0 \\
TOWR & 670 & 905 & 35.1 \\
MDKA & 1,050 & 1,700 & 61.9 \\
AALI & 13,200 & 16,000 & 21.2 \\
LSIP & 1,395 & 1,610 & 15.4 \\
\hline \multicolumn{3}{|c|}{ Total } & $\mathbf{2 5 6 . 8}$ \\
\hline
\end{tabular}

Table-2: Data of Stock's Closing Price, IHSG, and Risk Free Rate

\begin{tabular}{|lrrrrrrrrrrc|}
\hline MONTH & BMRI & BBNI & ICBP & INDF & TLKM & TOWR & MDKA & AALI & LSIP & IHSG & Rf \\
\hline Des & 7,675 & 7,850 & 11,150 & 7,925 & 3,970 & 805 & 1,070 & 14,575 & 1,485 & 6,300 & 0.004 \\
Jan & 7,550 & 7,200 & 11,375 & 7,825 & 3,800 & 845 & 1,170 & 11,875 & 1,175 & 6,058 & 0.004 \\
Feb & 7,275 & 7,025 & 10,275 & 6,500 & 3,490 & 805 & 1,305 & 9,800 & 970 & 5,453 & 0.004 \\
Mar & 4,680 & 3,820 & 10,225 & 6,350 & 3,160 & 675 & 1,015 & 5,400 & 840 & 4,539 & 0.004 \\
Apr & 4,460 & 4,100 & 9,875 & 6,525 & 3,500 & 900 & 1,230 & 6,100 & 710 & 4,716 & 0.004 \\
Mei & 4,470 & 3,830 & 8,150 & 5,750 & 3,150 & 955 & 1,300 & 7,400 & 690 & 4,754 & 0.004 \\
Jun & 4,950 & 4,580 & 9,350 & 6,525 & 3,050 & 1,020 & 1,365 & 8,225 & 830 & 4,905 & 0.004 \\
Jul & 5,800 & 4,600 & 9,200 & 6,450 & 3,050 & 1,135 & 1,790 & 9,700 & 990 & 5,150 & 0.003 \\
Ags & 5,950 & 5,100 & 10,225 & 7,625 & 2,860 & 1,035 & 1,740 & 10,175 & 980 & 5,238 & 0.003 \\
Sep & 4,960 & 4,440 & 10,075 & 7,150 & 2,560 & 1,035 & 1,615 & 10,175 & 905 & 4,870 & 0.003 \\
Okt & 5,775 & 4,740 & 9,650 & 7,000 & 2,620 & 990 & 1,830 & 10,875 & 980 & 5,128 & 0.003 \\
Nov & 6,325 & 6,000 & 9,900 & 7,100 & 3,230 & 1,095 & 1,940 & 12,325 & 1,190 & 5,612 & 0.003 \\
\hline
\end{tabular}

Table-3: The Output of Actual Return Calculation

\begin{tabular}{|lrrrrrrrrrrc|}
\hline MONTH & BMRI & BBNI & \multicolumn{1}{c|}{ ICBP } & INDF & TLKM & TOWR & MDKA & AALI & LSIP & IHSG & Rf \\
\hline Jan & -0.016 & -0.083 & 0.020 & -0.013 & -0.043 & 0.050 & 0.094 & -0.185 & -0.209 & -0.038 & 0.004 \\
Feb & -0.036 & -0.024 & -0.097 & -0.169 & -0.082 & -0.047 & 0.115 & -0.175 & -0.175 & -0.100 & 0.004 \\
Mar & -0.357 & -0.456 & -0.005 & -0.023 & -0.095 & -0.162 & -0.222 & -0.449 & -0.134 & -0.168 & 0.004 \\
Apr & -0.047 & 0.073 & -0.034 & 0.028 & 0.108 & 0.333 & 0.212 & 0.130 & -0.155 & 0.039 & 0.004 \\
Mei & 0.002 & -0.066 & -0.175 & -0.119 & -0.100 & 0.061 & 0.057 & 0.213 & -0.028 & 0.008 & 0.004 \\
Jun & 0.107 & 0.196 & 0.147 & 0.135 & -0.032 & 0.068 & 0.050 & 0.112 & 0.203 & 0.032 & 0.004 \\
Jul & 0.172 & 0.004 & -0.016 & -0.012 & 0.000 & 0.113 & 0.311 & 0.179 & 0.193 & 0.050 & 0.003 \\
Ags & 0.026 & 0.109 & 0.111 & 0.182 & -0.062 & -0.088 & -0.028 & 0.049 & -0.010 & 0.017 & 0.003 \\
Sep & -0.166 & -0.129 & -0.015 & -0.062 & -0.105 & 0.000 & -0.072 & 0.000 & -0.077 & -0.070 & 0.003 \\
Okt & 0.164 & 0.068 & -0.042 & -0.021 & 0.023 & -0.044 & 0.133 & 0.069 & 0.083 & 0.053 & 0.003 \\
Nov & 0.095 & 0.266 & 0.026 & 0.014 & 0.233 & 0.106 & 0.060 & 0.133 & 0.214 & 0.094 & 0.003 \\
\hline
\end{tabular}

\section{Portfolio Rate of Return Analysis}

The portfolio rate of return can be calculated by multiplying each rate of return stock with the fund proportion which is invested for each stock. The each proportion stock and the calculation result of portfolio rate return will be explained as follow:

Table-4: The Calculation Output of Fund Proportion in Each Stock

\begin{tabular}{|c|c|c|c|c|}
\hline Stock & Last Price (Rp) & $\begin{array}{c}\text { Target Price } \\
(\mathbf{R p})\end{array}$ & Upside (\%) & $\begin{array}{c}\text { Proportion } \\
(\boldsymbol{\%})\end{array}$ \\
\hline BMRI & 6,975 & 8,900 & 27.6 & 10.75 \\
BBNI & 7,500 & 10,600 & 42.3 & 16.08 \\
ICBP & 11,400 & 13,200 & 15.8 & 6.15 \\
INDF & 7,950 & 9,500 & 19.5 & 7.59 \\
TLKM & 3,950 & 4,700 & 19.0 & 7.40 \\
TOWR & 670 & 905 & 35.1 & 13.67 \\
MDKA & 1,050 & 1,700 & 61.9 & 24.10 \\
AALI & 13,200 & 16,000 & 21.2 & 8.26 \\
LSIP & 1,395 & 1,610 & 15.4 & 6.00 \\
\hline \multicolumn{4}{|r}{} \\
\hline
\end{tabular}


Table-5: The Calculation Output of Portfolio Return

\begin{tabular}{|lrrrrrrrrrr|}
\hline MONTH & BMRI & \multicolumn{1}{c}{ BBNI } & \multicolumn{1}{c}{ ICBP } & \multicolumn{1}{c|}{ INDF } & TLKM & TOWR & MDKA & \multicolumn{1}{l}{ AALI } & LSIP & Rp \\
\hline Jan & -0.016 & -0.083 & 0.020 & -0.013 & -0.043 & 0.050 & 0.094 & -0.185 & -0.209 & -0.017 \\
Feb & -0.036 & -0.024 & -0.097 & -0.169 & -0.082 & -0.047 & 0.115 & -0.175 & -0.175 & -0.036 \\
Mar & -0.357 & -0.456 & -0.005 & -0.023 & -0.095 & -0.162 & -0.222 & -0.449 & -0.134 & -0.242 \\
Apr & -0.047 & 0.073 & -0.034 & 0.028 & 0.108 & 0.333 & 0.212 & 0.130 & -0.155 & 0.113 \\
Mei & 0.002 & -0.066 & -0.175 & -0.119 & -0.100 & 0.061 & 0.057 & 0.213 & -0.028 & 0.001 \\
Jun & 0.107 & 0.196 & 0.147 & 0.135 & -0.032 & 0.068 & 0.050 & 0.112 & 0.203 & 0.103 \\
Jul & 0.172 & 0.004 & -0.016 & -0.012 & 0.000 & 0.113 & 0.311 & 0.179 & 0.193 & 0.134 \\
Ags & 0.026 & 0.109 & 0.111 & 0.182 & -0.062 & -0.088 & -0.028 & 0.049 & -0.010 & 0.021 \\
Sep & -0.166 & -0.129 & -0.015 & -0.062 & -0.105 & 0.000 & -0.072 & 0.000 & -0.077 & -0.074 \\
Okt & 0.164 & 0.068 & -0.042 & -0.021 & 0.023 & -0.044 & 0.133 & 0.069 & 0.083 & 0.063 \\
Nov & 0.095 & 0.266 & 0.026 & 0.014 & 0.233 & 0.106 & 0.060 & 0.133 & 0.214 & 0.126 \\
\hline Xi & 0.108 & 0.161 & 0.062 & 0.076 & 0.074 & 0.137 & 0.241 & 0.083 & 0.060 \\
\hline
\end{tabular}

Portfolio Performance Evaluation with Jensen Index

As mentioned at the first, this research used Jensen Index to evaluate the portfolio performance which is recommended by PT. Samuel Sekuritas Indonesia in January-

\section{December 2020 by considering these}

a. Jensen Index can be tested statistically

b. Jensen Index used beta $(\beta)$ as the risk measurement which assumed that PT. Samuel Sekuritas Indonesia as the investment company has formed portfolio which is well diversified.

It is the same as Treynor Index; Jensen Index is based on Theory Capital Asset Pricing Model which can be formulated as follow:

$$
\mathrm{R}_{\mathrm{pt}}-\mathrm{R}_{\mathrm{f}}=\alpha_{\mathrm{p}}+\beta_{\mathrm{p}}\left(\mathrm{R}_{\mathrm{Mt}}-\mathrm{R}_{\mathrm{ft}}\right)+\dot{\varepsilon}_{\mathrm{pt}}
$$

1. If alpha $(\alpha)$ significantly positive, the portfolio performance is superior
2. If alpha $(\alpha)$ significantly negative, the portfolio performance is inferior

3. If alpha $(\alpha)$ is not significantly different from zero, the portfolio performance is suitable with the market which is based on risk adjusted.

The hypothesis of this research:

$\mathrm{H}_{\mathrm{o}}=0$ (portfolio performance equals to market)

$\mathrm{H}_{\mathrm{a}} \neq 0$ (superior portfolio performance), $\alpha=5 \%$

By regression the excess return of PT. Samuel Sekuritas Indonesia portfolio with excess return of the market (IHSG) gained alpha $(\alpha) 0.029$ with tsig 0.048 . It means that alpha $(\alpha)$ significantly positive then the hypothesis of this research accepted.

The conclusion is that the portfolio performance of PT. Samuel Sekuritas Indonesia is superior. The further result calculating can be seen in this table below:

Table-6: The Calculation Output Excess Return Portfolio and Excess Return Market

\begin{tabular}{|llllrr|}
\hline Month & $\mathrm{Rp}$ & $\mathrm{Rf}$ & $\mathrm{Rm}$ & {$[\mathrm{Rp}-\mathrm{Rf}]$} & {$[\mathrm{Rm}-\mathrm{Rf}]$} \\
\hline Jan & -0.017 & 0.004 & -0.038 & -0.021 & -0.043 \\
Feb & -0.036 & 0.004 & -0.100 & -0.040 & -0.104 \\
Mar & -0.242 & 0.004 & -0.168 & -0.246 & -0.171 \\
April & 0.113 & 0.004 & 0.039 & 0.109 & 0.035 \\
Mei & 0.001 & 0.004 & 0.008 & -0.003 & 0.004 \\
Jun & 0.103 & 0.004 & 0.032 & 0.099 & 0.028 \\
Jul & 0.134 & 0.003 & 0.050 & 0.131 & 0.047 \\
Ags & 0.021 & 0.003 & 0.017 & 0.018 & 0.014 \\
Sep & -0.074 & 0.003 & -0.070 & -0.077 & -0.074 \\
Okt & 0.063 & 0.003 & 0.053 & 0.060 & 0.050 \\
Nov & 0.126 & 0.003 & 0.094 & 0.123 & 0.091 \\
\hline
\end{tabular}

Table-7: Normality Tested Output Descriptive Statistics

\begin{tabular}{|l|c|c|c|c|c|}
\hline \multirow{2}{*}{ N Statistic } & \multicolumn{2}{|c|}{ Skewness } & \multicolumn{2}{c|}{ Kurtosis } \\
\cline { 3 - 6 } & & Statistic & Std. Error & Statistic & Std. Error \\
\hline Unstandardized & 11 & -0.686 & 0.661 & 0.258 & 1.279 \\
\hline
\end{tabular}

$\begin{array}{ll}\text { Z_Skewness } & -0.929 \\ \text { Z_Kurtosis } & 0.175 \\ \text { Z_Kritis } & \pm 1.96\end{array}$


Table-8: Significant Intercept Tested Output Model Summary

\begin{tabular}{|c|c|c|c|c|c|}
\hline Model & $\mathbf{R}$ & & R Square & Adjusted R Square & Std. Error of the Estimate \\
\hline 1 & $.937^{\mathrm{a}}$ & & .878 & .865 & .0410202 \\
\hline
\end{tabular}

a. Predictors: (Constant), Excess return Market

\begin{tabular}{|c|c|c|c|c|c|}
\multicolumn{1}{|c|}{ ANOVA $^{\text {a }}$} \\
\hline & $\begin{array}{c}\text { Sum of } \\
\text { Squares }\end{array}$ & df & $\begin{array}{c}\text { Mean } \\
\text { Square }\end{array}$ & F & Sig. \\
\hline Regression Residual Total & .109 & 1 & .109 & 64.848 & $.000^{\mathrm{b}}$ \\
$\cdot$ & .015 & 9 & .002 & & \\
\hline & .124 & 10 & & & \\
\hline
\end{tabular}

a. Dependent Variable: Excess Return Portfolio

b. Predictors: (Constant), Excess returns Market

Coefficients $^{\mathrm{a}}$

\begin{tabular}{|l|c|c|c|c|c|}
\hline \multirow{2}{*}{ Model } & \multicolumn{2}{|c|}{ Unstandardized Coefficients } & Standardized Coefficients & t & Sig. \\
\cline { 2 - 6 } & B & Std. Error & Beta & & \\
\hline (Constant) & .029 & .013 & .937 & 2.291 & .048 \\
Excess return Market & 1.334 & .166 & & 8.053 & .000 \\
\hline
\end{tabular}

a. Dependent Variable: Excess Return Portfolio

Determination Coefficient $\left(\mathrm{R}^{2}\right)$ can be used to show the rate of diversification portfolio [3]. The higher Determination Coefficient is, the higher also the rate of diversification stock that form the portfolio. From the $8^{\text {th }}$ table, it can be seen that Determination Coefficient of the regression result between the excess return portfolio of PT. Samuel Sekuritas Indonesia toward excess return market showed up to 0.878 which means that $87.8 \%$ variation in return portfolio of PT. Samuel Sekuritas Indonesia can be explained by market portfolio. The conclusion is that the portfolio of PT. Samuel Sekuritas Indonesia has been well diversified.

\section{DISCUSSION}

The research result proved that alpha $(\alpha)$ excess return portfolio of PT. Samuel Sekuritas Indonesia has positive alpha $(\alpha)$ and it is significant. It means that the portfolio performance is superior. This superiority comes from these two sources [3]:

1. The portfolio manager may choose the stock which is undervalued and affected consistently the portfolio performance.

2. The portfolio manager may adjust the market change time, diversify the portfolio composition so it will be suitable with the up and down of the market. It is clear that the portfolio manager on PT. Samuel Sekuritas Indonesia has the ability to do those two things above. It is supported by the high Determination Coefficient $\left(\mathrm{R}^{2}\right) 0.878$ that indicates the portfolio manager ability in doing the diversification toward the stock formed as portfolio.

\section{CONCLUSION}

Based on the data analysis it can be concluded that the hypothesis testing proved which means that the portfolio performance of PT. Samuel Sekuritas Indonesia is superior with $\alpha=5 \%$ and $\mathrm{t}$ sig is 0.048 .

\section{SUGGESTION}

The suggestion for the next researcher is evaluate the portfolio performance in more investment company so it can give confidence for the investor's candidate that the investment company has the ability to form superior portfolio performance.

\section{REFERENCES}

1. Husnan, S. (2015). Dasar-Dasar Teori Portofolio dan Analisis Sekuritas, Kelima. Yogyakarta: UPP STIM YKPN, Yogyakarta.

2. Bodie Zvi, A. J. (2011). Kane Alex, Marcus, Investment and Portfolio Management, Ninth. New York: MeGraw - Hill Irwin.

3. Jones, C. P. (2007). Investmen, Tenth Edit. New York: John Wiley and Son Inc.

4. Elton, E. J., Gruber, M. J., Brown, S. J., \& Goetzmann, W. N. (2009). Modern portfolio theory and investment analysis. John Wiley \& Sons.

5. Suroto. (2020). "Analysis of Optimal Portfolio Selection and Portfolio Performance Evaluation on LQ45 Shares." 9414; 562-568. 